Agrosearch (2007) 9 No. 1\&2 43 - 51

\title{
FINANCIAL INTERMEDIATION IN AGRICULTURE IN NIGERIA: EMERGING ROLE OF NON-GOVERNMENTAL ORGANIZATIONS (NGOS)
}

\author{
*Oluwasola, O. and Alimi, T. \\ Department of Agricultural Economics, O. A. U, Ile-Ife, Nigeria. \\ Abstract
}

The study compared the credit operations of Farmers Development Union (FADU) - an $N G O$, with the Nigerian Agricultural Cooperative and Rural Development Bank (NACRDB) - a public sector finance agency in agricultural financing with a view to determining the emerging roles of NGOs in Nigeria's agricultural landscape. To achieve this, the socio-economic characteristics of farmers who use credit, and the performance of the selected credit institutions on the basis of credit delivery and loan repayment were identified and analysed using descriptive, t-test statistic and regression analyses. The results of the study revealed that the operational flexibility of the NGO was its major appeal to farmers. The use of groups as social assets for collateral instead of physical assets increased the vibrancy of the NGO compared to the public finance agency and provided a level playing field for both male and female farmers in the credit market. Patrons of the NGO made a mean savings of N22,284 whereas those of the public finance agency saved only N13,472. While the NGO disbursed more credit to its clients compared to the public finance agency, it also recovered $68.5 \%$ of its loans compared with $49.3 \%$ recovery made by the public finance agency. If formal banks will be able to impact on small farmers as the NGO, they will need to provide non-collaterized loans and to groups rather than individuals.

Key words: agricultural financing, farm capitalization, credit disbursement and loan recovery.

\section{Introduction}

Agriculture occupies a unique position in the economy of Nigeria. This is because when the total gross domestic product (GDP) is decomposed along sectoral lines, the economy is largely agrarian in structure (CBN, 2003; UNS, 2001). Although its position as the largest earner of foreign exchange during the first decade of independence has since been lost to crude oil export which presently accounts for over $80 \%$ of the nation's total export earnings, it still remains the largest sectoral contributor to the GDP as it contributed nearly $40 \%$ of the GDP. The sector employs $60 \%$ of the national labour force and accounts for $90 \%$ of the non-oil export earnings (UNS, 2001). Over the years, in spite of its mixed fortunes, the sector has continued to provide the bulk of the food requirements of the over 140 million Nigerians, especially the $70 \%$ of the populace who live in the rural areas and who are largely bypassed by imported food products.

The agricultural sector provides vast potentials to solving the problems of unemployment and poverty in the country. The nation has a total of 924,000 square kilometers ( 924 million hectares) of land area, $80 \%$ of which is arable (UNCED Report, 1992). Currently, only $50 \%$ of this is under cultivation. A total of 2.5 million hectares of land are capable of being brought under irrigation in the country, yet till date, only 974,900 hectares which represents $39 \%$ is under irrigation (FMWR, 1995). The small scale farmers constitute the bulk (about 60\%) of the farmers in Nigeria (Toluyemi, 1990; Oluwasola, 1999). It has also been estimated that $90 \%$ of 
the cultivated land in the country is still in the hands of the small scale farmers (FMAWR\&RD, 1986; NINCID, 2006).

These small holder farmers operating at low level of resource input are constrained by a number of factors among which is shortage of capital for overhead investment to increase farm productivity and resource conservation. Yet, a transformation of small scale subsistence farming that is mindful of the sustainability of the natural resource base requires the infusion of capital. In fact, the absence of this has been the major factor that has stalled the development of agriculture into a commercialized sector as several studies have shown (Ayanwale and Alimi, 2003; Ogundana, 1994; Osuntogun et al, 1992; Oni and Olomola, 1989 and Ogunfowora et al., 1972). Resources to obtain the required capital can either be obtained from within the agricultural sector in the form of savings or from without it in the form of credit. With low productivity and low earning potentials, farmers have very little to save. In addition, with low personal savings, the only other alternative to increasing farm capitalization is to use credit. Unfortunately, the operations of the credit market have not been favourable to the small scale farmers who do not possess the necessary collateral that formal banks require to guarantee loans (Zeller et al, 1997). In addition, the cumbersomeness and red-tapism associated with the formal banking sector effectively marginalize small scale farmers who are largely illiterate and whose enterprises are time dependent.

Recognizing these short comings, successive Nigerian governments have tried several programmes and policy measures to access farmers to credit. Such programmes include, the Nigerian Agricultural and Cooperative Bank (NACB) which was established in 1973 and later merged with the Peoples Bank and the Family Economic Advancement Programme to form the Nigerian Agricultural Cooperative and Rural Development Bank (NACRDB) in 2000. In 1977, the Central Bank of Nigeria also commenced the Agricultural Credit Guarantee Scheme Fund (ACGSF) to provide financial back-up for commercial banks who may incur bad debt through the failure of farmers to pay back loans. In spite of these policies, Nigerian farmers have continued to be bypassed by investible credit. Farmers still depend on informal sources for timely credit but these other sources are associated with very high interest rates. Incidentally, these informal sources have not been able to provide enough to satisfy the credit needs of farmers $r$ transform appreciably the peasant production techniques. Consequently, a number of non-governmental organizations (NGOs) have tried to fill the gap.

Since the debut of NGOs in 1981, they have extended their operations to cover the entire country (Anyanwu, 2004). Incidentally, very few studies have been done to critically examine their operations and compare them with public finance institutions to ascertain their suitability as an alternative to public sector-led financial agencies in providing credit to farmers and on sustainable basis. This study therefore set out to evaluate the operations of Farmers Development Union (FADU), a foremost NGO in agricultural financing, and compare its performance with the Nigerian Agricultural Cooperative and Rural Development Bank (NACRDB), a government financed development bank.

The main objective of this study was to compare operations of FADU, an NGO with NACRDB, a public agricultural financing institution, with a view to understanding the importance of the emerging role of NGOs in financing agriculture in Nigeria. Specifically, the study tried to:

i. determine the socio-economic characteristics of farmers who use credit from the two lending institutions; 
Ii. analyse the amount of loan supplied, interest rates charged and rate of recovery of loans given to beneficiaries, and,

iii. on the basis of objectives (i) and (ii)compare the performance of the two credit institutions.

\section{Methodology}

The study was conducted in three states Ogun, Oyo and Osun in the south western geopolitical zone of Nigeria for the 2005/2006 agricultural year. The selection of these states was purposive in that the incursion of NGOs into agricultural credit supply began here. In each of the states, 60 respondents were randomly selected from a list of loan beneficiaries supplied by FADU. In all, therefore, 180 respondent-clients of FADU were selected for the study. In addition, in each of the three states, 40 loan beneficiaries of NACRDB (making a total of 120 clients), were also interviewed. Structured questionnaires were used for the interview.

Descriptive statistics including frequency counts and percentages were used in analysing socio-economic characteristics of respondents while the student t-test statistic was used to compare the mean values obtained for variables among the two institutions. In addition, regression analyses were carried out to examine the factors determining the disbursement of credit to respondents between the two institutions. The model was specified as:

$\begin{array}{lll}\mathrm{Yi} & \mathrm{f}\left(\mathrm{X}_{1}, \mathrm{X}_{2}, \mathrm{X}_{3}, \mathrm{X}_{4}, U\right) \ldots \ldots \ldots \ldots \ldots \ldots \ldots \ldots \ldots \ldots \ldots \ldots \ldots \ldots \ldots \ldots \ldots \\ \mathrm{Where} & & \\ \mathrm{Y}_{\mathrm{i}}= & \text { total loan disbursed to respondents }(\mathrm{N}) \\ \mathrm{X}_{1}= & \text { amount of savings of respondents }(\mathrm{N}) \\ \mathrm{X}_{2}= & \text { amount of loan demanded by respondents }(\mathrm{N}) \\ \mathrm{X}_{3}= & \text { interest rate charged by credit institution } \\ \mathrm{X}_{4}= & \text { proportion of previous loans repaid } \\ U & = & \text { error term. }\end{array}$

The analysis was done separately for FADU and NACRDB clients. A priorily, all the variables were expected to be positively correlated to the level of disbursement of credit in the two financial institutions.

\section{Results and Discussions}

\section{Socio-economic and farm characteristics of loan beneficiaries}

Beneficiaries of credit facilities cut across gender as shown in Table 1. Of the total 270 respondents sampled, $66.7 \%$ were men while $33.3 \%$ were women. However, when participation was disaggregated along institutional lines, the study revealed that in the FADU, male beneficiaries only had a slight edge as there were $51.9 \%$ of male beneficiaries as against $48.1 \%$ female beneficiaries. With the NACRBD however, there was a marked difference as there were $88.9 \%$ male beneficiaries compared to $11.1 \%$ female beneficiaries. Clearly, the participation of women in credit operations is very high in the NGO compared to the NACRDB. Although set up primarily to service the agricultural and related sectors, the operational system of the NACRDB effectively excludes the access of women to its credit facilities. 
To advance credit, it requires collateral security which most women do not have. They do not have collaterals because they do not own tree crops they could pledge for loans and the land tenure system does not allow women to inherit land (Oluwasola, 1998). The NGOs where collaterals are not required thus become a viable alternative to women's credit needs hence, the very high rate of female participation in credit operations of FADU relative to the NACRDB. Although a micro credit scheme that does not require collateral was introduced into the programme of NACRDB after 2000, it is not known to the clients because it lacks grassroots' based network. Its programmes are posted on its website and on walls in its offices where small scale illiterate farmers who live in rural areas have little chance of being aware of.

The mean age of farmers who participated in FADU credit scheme was 44.9 years while that of NACRDB was 49 years. Thus, FADU farmers were relatively younger. The youthfulness of the FADU participants could stand them in good stead to accept change, take risks and explore new opportunities associated with the financing of agriculture by NGOs. However the t-test value of 0.01 showed that the difference in the mean age of the beneficiaries of the two credit delivery institutions was not significant. Consequently, participation in any of the two institutions was not related to age.

All the respondents had large family sizes although FADU participants had a larger family size. While the average family size for FADU farmers was 12.1, NACRDB was 9.3 (Table 1). Although large family sizes could be a sure source of labour supply in small scale farming where labour is the major critical resource after land, it could also mean high overheads for family consumption expenditure. The t-test value of -0.01 revealed that the difference in the mean family size of the FADU and NACRDB clients was not significant.

The two sets of farmers were fairly literate. As shown in Table 1, 53.7\% of FADU clients and $47.2 \%$ of NACRDB clients respectively had at least secondary education meaning they spent at least 12 years in school. Such a large number of literate farmer participants are crucial for extending new information on accessing credit and credit utilization as they will be able to comprehend the necessary process and techniques. Only $12.4 \%$ of the FADU respondents and $11.1 \%$ of NACRDB farmers did not have education at all. In any credit transaction with these sets of illiterates, the financial institutions will of need expend more resources of time and personnel. This transaction cost element will be higher for the NACRDB. With the NGO however, credit operation at the group level eliminates the problem thus conferring it with another advantage over the NACRDB.

All the FADU farmers belonged to farmers cooperative associations. About $90.7 \%$ NACRDB farmers also belonged to farmers associations. As shown in Table 1, only $64.8 \%$ of FADU respondents and $65.8 \%$ of NACRDB respondents respectively were full time farmers. The remaining combined farming with other economic activities including civil service, trading, and artisans. While engagement in secondary occupation allows for diversification of income sources which is a positive hedge against enterprise failure and hence poverty, it could also affect the effective utilization of credit as farm loans could easily be diverted to finance non-farm activities. While this could lead to loan delinquency in NACRDB, the use of groups as collateral will effectively check this problem in FADU as members have savings with the organization.

The farming experience of respondents is nearly similar between the two groups of farmers. While respondents of FADU scheme had an average of 23.5 years experience in farming, those of NACRDB had 24.1 years (Table 1). These long years of experience Oluwasola and Alimi 
could be critical in determining the capability of farmers to seek for new ideas and also make use of credit funds profitably. The t-test value of 0.01 indicated that the difference in the mean experience of FADU and NACRDB farmers was not statistically significant.

Farm sizes also averaged 5.1 hectares for FADU farmers as against 4.4 hectares for NACRDB farmers (Table 1). Compared to average farm size in Nigeria which is 2.0 hectares (Oluwasola, 1996; Idachaba, 1989) respondents operated large farm lands. This might have resulted from the fact that respondents had access to credit for farm operations. Large farm sizes also have their advantages for the credit system as all things being equal, large farm sizes could positively affect total farm income. Increased farm earnings will in turn enable farmers meet their credit obligations after meeting family needs from their farming operations. The t-test value of 0.69 shows that the difference in the mean farm sizes of FADU and NACRDB farmers was statistically significant.

In addition to the two financial institutions studied, respondents also obtained loans from other sources like the cooperative societies, esusu groups (rotatory loan schemes), women's groups and farmers unions. It is instructive to note that none of the respondents got any loan from commercial banks. As shown in Table 2, the FADU respondents obtained an average of N12,788 from these other sources while those of NACRDB obtained N11,806. The t-test value of 0.39 indicated that there was no significant difference in the mean value of amount of credit borrowed from other sources by respondents of both institutions.

\section{Credit Operations of FADU and NACRDB}

The process for credit delivery differed among the two institutions. FADU advances group loans and encourages its loan beneficiaries to save. It was a precondition to been advanced credit. NACRDB however advances loans to individual farmers. Although NACRDB also has as one of its goals the development of banking culture at the grass root especially the culture of savings, the amount of credit it advances beneficiaries is not tied to their level of savings. As indicated in Table 3 , all the FADU respondents saved with $85.2 \%$ of its loan beneficiaries saving more than N10,000. Only $14.8 \%$ saved less than this amount. In contrast, $17.6 \%$ of the loan beneficiaries of the NACRDB scheme did not save at all while $37.0 \%$ of these group saved less than N10,000. The mean amount saved by FADU respondents was N22,284 while that of NACRDB respondents was only N13,472. The t-test value of 0.02 showed that the difference in the mean value of savings among FADU and NACRDB clients was not statistically significant.

Table 4 showed the amount of loan requested by respondents. The mean amount requested by FADU beneficiaries was N75,741 whereas, the NACRDB respondents who saved less on the average requested for $\mathrm{N} 87,223$. As a public institution, the Nigerian public have come to view the NACRDB and whatever they can get out of it as a public good that should be consumed without measure whether or not they have the capacity to absorb the credit. In FADU however, the amount a client could request for is closely tied to the amount of savings he/she has made. However, the t-value of 0.01 indicated that there was no significant difference in the mean values of amount of loan requested by the two groups of respondents.

Table 5 shows the actual amount disbursed by the two credit institutions. The table revealed that FADU gave out more loans to its participants compared to the NACRDB. While only $8.6 \%$ of FADU respondents were advanced the least credit class of up to N20,000, up to $13 \%$ of the NACRDB respondents got this same amount. Again, while only $45.7 \%$ of the FADU respondents got up to $\mathrm{N} 60,000,77.8 \%$ of NACRDB respondents received same amount. On the 
average, FADU gave out N59,260 to its clients while NACRDB gave only N45,000. FADU's disbursement represented $80 \%$ of the total loan requested from it by its clients while the disbursement of NACRDB was just $52 \%$ of the

total request it received. Clearly, the NGO made more impact in terms of accessing farmers to credit relative to the public finance institution. However, the t-test value of 0.02 obtained indicated that the difference in the mean amount of loan disbursed was not statistically significant.

For the year 2005 credit cycle, FADU achieved $68.5 \%$ credit recovery while NACRDB recovered only $49.3 \%$ of the loans it disbursed.

\section{Factors determining credit disbursement in FADU and NACRDB}

Equations (2) and (3) show the factors determining credit disbursement in FADU and NACRDB respectively. The two models show that the amount of savings made by the farmers $\left(\mathrm{X}_{1}\right)$, the amount of loan demanded $\left(\mathrm{X}_{2}\right)$, the prevailing interest rate charged $\left(\mathrm{X}_{3}\right)$ and the proportion of previous loans repaid $\left(\mathrm{X}_{4}\right)$ were positive determinants of the amount of credit disbursed and were in conformity with a priori expectation. In equation (2), all the variables were statistically significant except interest rate while in equation (3), only the level of savings made by farmers was not statistically significant.

Equation (2) shows that the level of savings achieved by the farmer in receiving loans from FADU is critical and statistically significant. A unit increase in the level of savings will increase loan disbursement to the farmers by $6 \%$. Also, the amount of loan applied for from FADU is very significant as a unit increase in the demand for credit will increase lending from FADU by $79 \%$. This is quite understandable since in the operations of FADU, farmer beneficiaries must have saved between $25 \%$ and $50 \%$ of whatever loan they are asking for. Finally, a unit increase in the proportion of previous loans repaid will lead to $148 \%$ increase in loans disbursed by FADU to the farmers. These three variables were also statistically significant. Although interest rate showed a positive correlation with loan disbursed by FADU, it was not statistically significant. The adjusted coefficient of variation 0.801 indicates that about $80 \%$ of the variability in the factors determining loan disbursement by FADU is associated with the explanatory variables specified in the model.

$$
\begin{array}{r}
\operatorname{LnY}_{1}=4.34+0.0581 * \ln X_{1}+0.788 * \ln X_{2}+0.236 \ln X_{3}+1.482 * \ln X_{4} \ldots \ldots(2) \\
(0.664) \quad(6.113) \quad(0.869) \quad(1.538) \\
R^{2}=0.842 ; \quad \operatorname{adjR}^{2}=0.801 ; \quad F=102.105
\end{array}
$$

Equation (3) shows that in the operations of NACRDB, the amount of loan applied for by farmers, interest rates charged, and proportion of previous loan repaid were statistically significant factors affecting its credit transactions with farmers. As shown, a unit increase in the amount of loan applied for by farmer beneficiaries will increase lending by $42 \%$ while a unit increase in interest rate will only lead to $5 \%$ increase in credit advancement to farmers. Finally, a unit increase in the proportion of previous loan repaid will increase credit advancement by $11 \%$. Level of savings made by farmers was positively correlated with the credit disbursement by NACRDB although, it was not statistically significant. 


$$
\begin{array}{r}
\operatorname{LnY}_{2}=5.277+0.544 \ln X_{1}+0.416 * \ln X_{2}+0.052 * \ln X_{3}+0.113 * \ln X_{4} \ldots \ldots .(3) \\
(7.658) \quad(10.320) \quad(1.471) \quad(2.546) \\
R^{2}=0.641 ; \quad \operatorname{adjR}^{2}=0.638 ; \quad F=152.237
\end{array}
$$

It is thus obvious that the sustainability of FADU is quite ensured as the level of savings deposit made by beneficiaries is crucial. This not only made credit available for the use of farmers, it also increases the capitalization of the credit institution in the long term. Since the cost of credit is market determined, it ensures the prudent use of credit . On the contrary, the level of savings was not significant in the operations of NACRDB. This makes its continued existence as well as efficiency to be dependent on the level of commitment shown it by government.

\section{Conclusion and Recommendation}

The study has demonstrated the emerging trend in agricultural financing. The result from the study shows that on the whole, men continue to dominate in the operations of agricultural credit market. However, the operational flexibility of the NGO in terms of demand for collaterals has made it more appealing and hence, more women participated in it than in the formalized financial institution studied. The initiative of the NGO is quite acceptable to the younger and more enterprising members of the agricultural households sampled as the mean age of the respondents of FADU was 44.9 years whereas, the mean age of the respondents of NACRDB was 49 years.

The level of literacy was generally high among the two groups of respondents. However, the over head cost for credit transaction for beneficiaries that will likely be incurred will be lower in FADU compared to NACRDB. This is because while NACRDB will have to open files and deal with each individual beneficiary, FADU has only to deal with the group. The few illiterates who will not even be able to fill forms will further compound the administrative problem of credit transactions in the NACRDB.

The NGO credit system has a stronger prospect for sustainability compared to the public finance financial institution because it encouraged its participants to save. In the FADU, savings was a precondition for and a determinant of the amount that could be borrowed by any client. The implication of this is that the sustainability of NACRDB depends on the good will of government. Unfortunately, this good will is shrinking daily with the new economic reforms which place more emphasis on a private rather than a public sector led development strategy.

The indifference of farmers to the very high interest rates charged by FADU which is comparable and even higher than the rate charged by commercial banks compared to the subsidized interest rate charged by the NACRDB shows that farmers need not and are not demanding for subsidized credit. The major constraint to their accessing credit is the collateral demanded by banks. The practice of the NGO is strongly recommended to the formal banks. The NGO organizes participants into cooperative groups for credit transactions and encourages the loan beneficiaries to save. The group becomes the collateral for the advancement of loans. The formal banks should also open a window especially at their rural branches where farmers could save. The farmers who patronize them should then be encouraged to organize themselves into registered cooperative groups to eliminate the need for physical assets as collaterals and for easy credit administration. This process will ensure that farmers groups, through group pressure, can ensure that loans are repaid. In addition, the savings of the farmers will ensure the sustainability of the credit system. The result of the study also shows that respondents in both 
institutions have very large family sizes (12.1 in FADU and 9.3 in NACRDB). This is not good for long term capital accumulation among the farmers. In fact, productive credit advanced farmers with large family sizes could end up in consumption expenditure thus adversely affecting the farm production enterprise and consequently the ability of such farmers to repay their

loans. It is thus important that family planning services be accessed farm families in the rural areas. Fortunately, this is one of the services being rendered by FADU.

\section{References}

Anyanwu, C.M. (2004) 'Microfinance Institutions in Nigeria: Policy, Practice and Potentials'. Paper presented at the G24 workshop on 'Constraints to Growth in Sub-Saharan Africa', Pretoria, South Africa, Nov. 29 30, 2004.

Ayanwale A.B. and Alimi, T. (2003) 'Micro financing as a Poverty Alleviation Measure: A Gender Analysis'. Journal of Social Science, Vol.42 No.1, Pp: 1-7

Central Bank of Nigeria (CBN) (2003), 'Annual Report and Statement of Accounts', December 31, 2003, CBN.

Federal Ministry of Agriculture, Water Resources and Rural Development (FMAWR\&RD), 1986 'Agricultural Policy for Nigeria'. Federal Ministry of Water Resources (FMWR), 1995 'National Survey on Irrigation in Nigeria'.

Idachaba, F.S. (1989) 'The Implications of Forest Fires and Bush Burning for Nigerian Food Production Strategies'. Lecture delivered on the occasion of World Environment Day, Lagos, FEPA Special Publication No. 2, pp 721

Nigerian National Committee on Irrigation and Drainage (2006) Annual Report, 2006.

Ogundana B.A. (1994) Comparative Analysis of the Performance of UBA Credit Scheme for Rural Women in Ondo, Osun and Oyo States of Nigeria. Unpublished M.Sc thesis, Department of Agricultural Economics, Obafemi Awolowo University, Ile- Ife. $160 \mathrm{pp}$.

Ogunfowora O; Essang, S.M. and S.O. Olaide (1972) ' Capital Investment in Farming: An Appraisal of Selected Communities in Kwara State'. Nigeria Journal of Economics and Social Studies. 19 (3): 382386

Oluwasola, O. (1996).'Selecting an Optimal Farm Enterprise Combination in Traditional Agroforestry Systems Using Portfolio Model Analysis. Agrosearch, A Journal of Agriculture, Food and Development, Vol.2 Nos. 1 and 2, pp 67 - 80

Oluwasola, O.(1998) 'Women in Agriculture in Nigeria' In Amadu Sesay and Adetanwa Odebiyi (Eds.) Nigerian Women in Society and Development Dokun Publishing House, Ibadan.

Oni S.A and A.S.A Olomola (1989) 'Techniques for Attracting Credit for Financing Agricultural Development in Africa'. Proceedings of the $6^{\text {th }}$ Symposium of Association of Africa Central Bank, Abuja Nigeria. PP 103110.

Osuntogun, C.A.; B.O. Oramah and J.O. Olusi (1992) 'The Impact of Specialized SmallHolder Credit Programmes on Farmer Beneficiaries: A Case Study of the First Bank of Nigeria'. African Review of Money, Finance and Banking 1/92

Toluyemi, T. (1990) 'Food for all in Nigeria: A Grassroot Agricultural Financing Option'. Paper presented at the National Seminar on Agricultural Financing and Credit Management, Kaduna, 2526 October, 1990. 
Oluwasola and Alimi

United Nations System in Nigeria (UNS, 2001) Nigeria Common Country Assessment, March 2001.

Zeller, M., Schrieder, G., Von Braun, J., and Heidhues, F (1997) Rural Finance for Food Security for the Poor: Implications for Research and Policy. Food Policy Review 4, International Food Policy Research Institute (IFPRI), Washington, D.C.

Table 1:Socio-Economic Characteristics of Respondents

\begin{tabular}{|c|c|c|c|c|}
\hline No. & Characteristic & $\begin{array}{l}\text { FADU } \\
\text { Respondents }\end{array}$ & $\begin{array}{l}\text { NACRDB } \\
\text { Respondents }\end{array}$ & t-value* \\
\hline 1. & $\begin{array}{l}\text { Gender: } \\
\text { Male } \\
\text { Female }\end{array}$ & $\begin{array}{l}51.9 \% \\
48.1 \%\end{array}$ & $\begin{array}{l}88.9 \% \\
11.1 \%\end{array}$ & - \\
\hline 2. & Mean age & 44.9 years & 49.0 years & 0.01 \\
\hline 3. & Mean family size & 12.1 & 9.3 & -0.01 \\
\hline 4. & $\begin{array}{l}\text { Education: } \\
\text { No education } \\
\text { Up to primary school } \\
\text { Secondary school } \\
\text { Tertiary }\end{array}$ & $\begin{array}{l}12.4 \% \\
29.0 \% \\
43.2 \% \\
10.5 \%\end{array}$ & $\begin{array}{l}11.1 \% \\
38.0 \% \\
35.2 \% \\
12.0 \%\end{array}$ & - \\
\hline 5. & $\begin{array}{l}\text { Occupation: } \\
\text { Full time farming } \\
\text { Civil servants/farming } \\
\text { Trading/farming } \\
\text { Artisan/farming } \\
\text { Local industrialist/farming } \\
\text { Musician/farming }\end{array}$ & $\begin{array}{c}64.8 \% \\
6.2 \% \\
11.7 \% \\
9.9 \% \\
4.3 \% \\
3.1 \%\end{array}$ & $\begin{array}{r}65.8 \% \\
4.6 \% \\
12.6 \% \\
11.1 \% \\
3.7 \% \\
1.9 \%\end{array}$ & - \\
\hline 6. & Farming experience & 3.5 years & 24.1 years & 0.01 \\
\hline 7. & Farm size & 5.1 ha & $4.4 \mathrm{ha}$ & $0.69 * *$ \\
\hline 8. & $\begin{array}{l}\text { Types of crops grown: } \\
\text { Food crops only } \\
\text { Cash crops only } \\
\text { Food and cash crops }\end{array}$ & $\begin{array}{l}51.9 \% \\
1.9 \% \\
46.2 \%\end{array}$ & $\begin{array}{l}48.2 \% \\
4.6 \% \\
47.2 \%\end{array}$ & - \\
\hline 9. & $\begin{array}{l}\text { Membership of associations: } \\
\text { Cooperative societies } \\
\text { Farmers union } \\
\text { Women's groups } \\
\text { Cooperative/farmers union } \\
\text { Cooperative/women's group } \\
\text { Does not belong to any }\end{array}$ & $\begin{array}{l}30.9 \% \\
30.2 \% \\
2.8 \% \\
9.3 \% \\
6.8 \% \\
0.0 \%\end{array}$ & $\begin{array}{r}28.7 \% \\
31.5 \% \\
8.3 \% \\
20.4 \% \\
9.3 \% \\
9.3 \%\end{array}$ & - \\
\hline
\end{tabular}

Source: Field survey, 2006 
Oluwasola and Alimi

Table 2: Distribution of Respondents by Amount Borrowed from other sources

\begin{tabular}{lcccc}
\hline Amount borrowed & \multicolumn{2}{c}{ FADU } & \multicolumn{2}{c}{ NACRDB } \\
From other sources & Frequency & $\%$ & Frequency & $\%$ \\
\hline$<5,001$ & 28 & 17.3 & 21 & 19.4 \\
$5,001-10,000$ & 34 & 21.0 & 33 & 30.6 \\
$10,001-15,000$ & 47 & 29.0 & 25 & 23.1 \\
$15,001-20,000$ & 23 & 14.2 & 11 & 10.2 \\
$20,001-25,000$ & 16 & 9.9 & 8 & 7.4 \\
$25,001-30,000$ & 12 & 7.4 & 7 & 6.5 \\
$>30,000$ & 2 & 1.2 & 3 & 2.8 \\
Total & 162 & 100.0 & 108 & 100.8 \\
Mean & N 12,788 & & N 11, 806 \\
& t-value $=0.39$ & & & \\
\hline
\end{tabular}

Source: Field survey, 2006

Table 3: Savings Distribution between FADU and NACRDB Respondents

\begin{tabular}{lcccr}
\hline Savings (N) & \multicolumn{2}{c}{ FADU } & \multicolumn{2}{c}{ NACRDB } \\
& Frequency & $\%$ & Frequency & $\%$ \\
\hline None & - & - & 19 & 17.6 \\
$<10,001$ & 24 & 14.8 & 40 & 37.0 \\
$10,001-20,000$ & 58 & 35.8 & 20 & 18.5 \\
$20,001-30,000$ & 48 & 29.6 & 15 & 13.9 \\
$30,001-40,000$ & 13 & 8.1 & 7 & 6.5 \\
$40,001-50,000$ & 8 & 4.9 & 5 & 4.6 \\
$>50,000$ & 11 & 6.8 & 2 & 1.9 \\
Total & 162 & 100.0 & 108 & 100.0 \\
Mean & N 22,284 & & N 13,472 & \\
& t-value $=0.02$ & & & \\
\hline
\end{tabular}

Source: Field survey, 2006

Table 4: Distribution of Respondents by Amount of Loan Requested

\begin{tabular}{lcccc}
\hline Amount of loan requested & \multicolumn{2}{c}{ FADU } & \multicolumn{2}{c}{ NACRDB } \\
& Frequency & $\%$ & Frequency & $\%$ \\
\hline$<30,001$ & 12 & 7.4 & 6 & 5.6 \\
$30,001-60,000$ & 44 & 27.2 & 15 & 13.9 \\
$60,001-90,000$ & 60 & 37.0 & 32 & 29.6 \\
$90,001-120,000$ & 20 & 12.4 & 39 & 36.1 \\
$>120,000$ & 26 & 16.0 & 16 & 14.8 \\
Total & 162 & 100.0 & 108 & 100.8 \\
Mean & N 75,741 & & N 87,223 \\
& t-value $=0.01$ & & \\
\hline
\end{tabular}

Source: Field survey, 2006 
Oluwasola and Alimi

Table 5: Distribution of Respondents by Amount of Loan Granted

\begin{tabular}{lcrrr}
\hline Amount of loan granted & \multicolumn{2}{c}{ FADU } & \multicolumn{2}{c}{ NACRDB } \\
& Frequency & $\%$ & Frequency & \multicolumn{1}{c}{$\%$} \\
\hline$<20,001$ & 14 & 8.6 & 15 & 13.9 \\
$20,001-40,000$ & 28 & 17.3 & 38 & 35.2 \\
$40,001-60,000$ & 32 & 19.8 & 31 & 28.7 \\
$60,001-80,000$ & 58 & 35.8 & 12 & 11.1 \\
$80,001-100,000$ & 17 & 10.5 & 7 & 6.5 \\
$>100,000$ & 13 & 8.0 & 5 & 4.6 \\
Total & 162 & 100.0 & 108 & 100.8 \\
Mean & N 59,260 & & N 45,000 & \\
& t-value $=0.02$ & & & \\
\hline
\end{tabular}

Source: Field survey, 2006 